\title{
ANALISIS FAKTOR DETERMINAN TERJADINYA KECENDERUNGAN KECURANGAN (STUDI PADA PEMERINTAH PROVINSI PAPUA)
}

\author{
Hesty Theresia Salle \\ hezty.salle@gmail.com \\ Meinarni Asnawi \\ meinarni.asnawi@gmail.com \\ Anthonius H. Citra Wijaya \\ anthoniuscitra@gmail.com
}

\begin{abstract}
Abstrak
The study conducted to examine the effects of compensation suitability, leadership authority, internal control system, information asymmetric, regulatory enforcement and moral reasoning to the fraud tendency-unethical behaviour used as mediating variable. I raised the data using a survey. The data is analyzed using WrapPLS 6.0 application. The result shows that the leading authority and moral reasoning have an effect on the tendency of fraud, while compensation suitability, internal control system, information asymmetry, regulatory enforcement, and unethical behaviour has no effect. Furthermore, unethical behaviour does not mediate the compensation suitability, leadership authority, internal control system, information asymmetry, regulatory enforcement, and moral reasoning.
\end{abstract}

Keywords: fraud, keadership, compensation, leadership, internal control, information asymmetric, regulatory enforcement, moral reasoning

\section{PENDAHULUAN}

Hampir satu dekade ini kasus-kasus terkait fraud atau yang biasa disebut dengan kecurangan dalam bidang keuangan menjadi sorotan publik dan media massa di Indonesia, khususnya tindakan fraud yang dilakukan oleh aparat birokrasi di Pemerintahan (Syahadat \& Damayanti, 2017). Semakin berkembangnya fraud, pelaku pun tidak terbatas pada golongan atas, namun sudah banyak menyentuh lapisan pegawai bawah (Hadi, 2016). Provinsi Papua merupakan salah satu daerah yang tidak terlepas dari adanya praktik-praktik kecurangan yang dilakukan oleh oknum-oknum dalam pemerintahan. Bahkan dikatakan, Provinsi Papua termasuk dalam sepuluh wilayah rawan tindak pidana korupsi ${ }^{1}$ (Salle \& Burg, 2019) .

\footnotetext{
${ }^{1}$ http://tabloidjubi.com/artikel-7053-papua-masuk-10-wilayah-rawan-tindak-pidana-korupsi-.html
} 
Berdasarkan hasil pemeriksaan BPK atas Laporan Keuangan Pemerintah Daerah Provinsi Papua TA $2016^{2}$, ditemukan adanya ketidakpatuhan dan kecurangan. Beberapa temuan BPK terkait ketidakpatuhan dan kecurangan, antara lain: a) pengelolaan belanja hibah dan bantuan sosial, yang mana penyaluran bantuan sosial yang tidak direncanakan melebihi proporsi bantuan sosial yang direncanakan, serta masih banyaknya penerima bantuan sosial yang tidak memenuhi kriteria terkena bantuan sosial yang mengakibatkan pemborosan keuangan daerah Provinsi Papua atas belanja bantuan sosial yang tidak memenuhi kriteria, b) pertangungjawaban belanja perjalanan dinas pada OPD yang tidak sesuai ketentuan dikarenakan bukti pertanggungajwaban lebih tinggi dibanding harga tiket pada sistem, dan juga adanya perjalanan dinas yang tidak dilaksanakan atau diragukan keterjadiannya, dan c) kecurangan dalam pengadaan peningkatan jalan Kemiri-Depapre, yaitu penyalahgunaan wewenang untuk menguntungkan diri sendiri, orang lain dan korporasi sehingga menyebabkan kerugian Negara.

Fenomena kasus kecurangan yang dilakukan oleh aparat pemerintahan baik pimpinan maupun staf bukanlah hal yang baru terjadi. Banyak faktor penyebab sehingga baik itu pimpinan maupun staf melakukan tindakan kecurangan. Dalam teori fraud triangle yang diperkenalkan oleh Cressey (1953) dalam Kassem \& Higson (2012) disebutkan ada 3 (tiga) faktor yang menggambarkan alasan mengapa seseorang melakukan kecurangan, yaitu: pressure, opportunity, dan razionalization. Adapula teori GONE yang dikembangkan oleh Bologne (1993) yang menyebutkan bahwa alasan seseorang melakukan kecurangan karena greed, opportunity, need, dan exposure.

Penelitian-penelitian terkait faktor-faktor penyebab terjadinya kecenderungan kecurangan sudah dilakukan oleh beberapa peneliti sebelumnya seperti penelitian yang dilakukan oleh Mustika, Hastuti, \& Heriningsih (2016) yang hasilnya menyatakan bawah faktor-faktor seperti penegakan peraturan dan perilaku tidak etis dapat mendorong seseroang untuk melakukan kecurangan. Penegakan peraturan yang rendah akan menjadi

\footnotetext{
2 Laporan Hasil Pemeriksaan atas Laporan Keuangan Pemerintah Daerah Provinsi Papua Tahun Anggaran 2016
} 
celah untuk melakukan kecurangan, selain itu perilaku tidak etis akan meningkatkan peluang terjadinya kecurangan. Namun, faktor-faktor seperti efektifitas pengendalian internal, asimetri informasi dan kesesuaian kompensasi tidak memiliki pengaruh terhadap kecenderungan kecurangan. Adapula penelitian Puspasari \& Surwardi (2012) yang menguji moralitas individu dan sistem pengendalian internal terhadap kecenderungan kecurangan, memperoleh hasil bahwa individu dengan penalaran moral tinggi cenderung tidak melakukan kecurangan baik dalam kondisi terdapat sistem pengendalian internal maupun tidak ada sistem pengendalian internal. Namun, individu dengan penalaran moral rendah cenderungan tidak melakukan kecurangan dalam kondisi terdapat pengendalian internal, sebaliknya dalam kondisi tidak terdapat pengendalian internal, individu dengan level penalaran moral rendah akan cenderungan melakukan kecurangan.

Selanjutnya ada juga penelitian Permatasari, Kurrohman, \& Kartika (2017) yang hasil penelitiannya menunjukkan bahwa faktor kesesuaian kompensasi dan keefektifan pengendalian internal tidak memiliki pengaruh terhadap kecenderungan kecurangan pada pegawai keuangan Pemerintah Kabupaten Banyuwangi, sedangkan gaya kepemimpinan, kultur organisasi, asimetri informasi, perilaku tidak etis dan penegakan hukum memiliki pengaruh terhadap kecenderungan kecurangan. Korompis, Saerang, \& Morasa (2018) yang menggunakan variabel moralitas individu, asimteri informasi dan sistem pengendalian internal, dimana ketiga variabel tersebut sama-sama memiliki pengaruh terhadap kecenderungan untuk melakukan kecurangan.

Pada penelitian ini peneliti ingin menganalisis kembali faktor-faktor yang penyebab terjadinya kecenderungan kecurangan oleh Mustika et al., (2016) dengan menggunakan variabel yang sama, namun dengan model penelitian yang berbeda, lokasi penelitian yang berbeda dan alat analisis yang berbeda. Penelitian ini ingin menguji pengaruh variabel kesesuai kompensasi, otoritas pimpinan, sistem pengendalian internal, asimetri informasi, penegakan peraturan, dan penalaran moral terhadap kecenderungan kecurangan dengan perilaku tidak etis sebagai mediasi. Sehingga berdasarkan uraian di atas, tujuan dalam 
penelitian ini adalah untuk menguji dan menganalisis faktor-faktor penyebab terjadinya kecenderungan kecurangan.

\section{LANDASAN TEORI DAN PENGEMBANGAN HIPOTESIS}

\section{Landasan Teori}

\section{Teori Fraud Triangle}

Tahun 1950an seorang ahli kriminologi yaitu Donald Cressey memulai studi tentang kecurangan dan dalam argumennya dikatakan bahwa harus ada alasan dibalik segala sesuatu yang orang lakukan (Cressey, 1953) dalam Abdullahi \& Mansor (2015). Penelitiannya berfokus pada faktor apa yang mendorong seseorang melakukan kecurangan. la menemukan bahwa ada tiga faktor bagi seseorang untuk melakukan kecurangan, yaitu tekanan, kesempatan dan rasionalisasi.

Tekanan berkaitan dengan motivasi yang mengarah pada perilaku tidak etis. Tekanan yang muncul, antara lain: tekanan keuangan, tekanan pekerjaan, tekanan akan kebiasaan buruk, dan lainnya. Kecurangan yang dipicu oleh kesempatan dikarenakan kecurangan tersebut mudah dilakukan, yang biasanya terjadi karena lemahnya pengendalian internal organisasi, kurangnya pengawasan, dan sebagainya. Sedangkan, rasionalisasi adalah pemikiran yang menjustifikasi bahwa tindakannya sebagai suatu perilaku yang wajar, yang secara moral dapat diterima dalam suatu masyarakat yang normal.

\section{Teori GONE}

Teori GONE yang diperkenalkan oleh Bologne (1993), merupakan penyempurnaan dari teori fraud triangle Cressey (1953). Dalam teori ini ada empat komponen penyebab seseorang melakukan kecurangan yaitu Greed (keserakahan), Opportunity (kesempatan), Need (kebutuhan), dan Exposure (pengungkapan), yang mana Greed dan Need merupakan faktor internal, sedangkan Opportuniy dan Exposure merupakan faktor eksternal.

Berdasarkan teori GONE faktor internal seseorang melakukan kecurangan karena memang pada dasarnya manusia memiliki sifat serakah dan tak pernah merasa puas, serta didesak oleh kebutuhan hidup yang semakin banyak. Sedangkan, faktor eksternal seseorang 
melakukan kecurangan karena adanya kesempatan dari lingkungan sekitar pelaku sehingga menimbulkan keinginan untuk melakukan kecurangan.

\section{Pengembangan Hipotesis}

\section{Kesesuaian kompensasi, kecenderungan kecurangan, dan perilaku tidak etis}

Dalam teori fraud triangle dan teori GONE, salah satu penyebab seseorang melakukan kecurangan karena adanya tekanan dan keserakahan. Pada umumnya yang mendorong terjadinya kecurangan karena tekanan finansial, namun banyak pula yang terdorong oleh keserakahan (Diany \& Ratmono, 2014). Seseorang akan cenderung melakukan kecurangan jika merasa bahwa penghasilan yang diterima tidak mencukupi kebutuhannya, namun saat ini banyak orang yang melakukan kecurangan bukan hanya karena merasa bahwa penghasilan yang diterima kurang, bahkan seseorang dengan penghasilan tinggipun tidak terlepas dari tindakan kecurangan.

Penelitian Apriadi \& Fachriyah (2014) yang dilakukan pada pegawai BPK RI Perwakilan Provinsi Jawa Timur memberikan hasil bahwa kesesuaian kompensasi memiliki hubungan terhadap terjadinya fraud. Hal ini berarti semakin sesuai kompensasi yang diterima, maka akan menurukan kecenderungan untuk melakukan fraud. Arles (2014) dalam penelitiannya memperoleh hasil bahwa model incentive yang tidak sesuai dengan jabatan atau tidak terpenuhinya kebutuhan mendorong seseorang melakukan tindakan usaha untuk memenuhinya dengan cara yang lain. (Amrizal, 2004) menyatakan bahwa kecurangan dapat terjadi bila pegawai memiliki maslaah pribadi yang tidak dapat dipecahkan, biasanya masalah kecurangan, kebutuhan kesehatan, ataupun gaya hidup yang berlebihan.

Penelitian Pratiwi, DP, \& Rofika, 2016; Shintadevi (2015) mencoba untuk menemukan hubungan antara kesesuaian kompensasi dan perilaku tidak etis yang muncul karena pegawai merasa tidak puas atas hasil yang sudah diperoleh dari instansi. Dan hasil 
penelitiannya memberikan hasil bahwa sistem kompensai memiliki pengaruh terhadap kecenderungan kecurangan melakukan perilaku tidak etis.

$\mathrm{H1a}$ : Kesesuaian kompensasi berpengaruh negatif terhadap kecenderungan kecurangan

$\mathrm{H} 1 \mathrm{~b}$ : Kesesuaian kompensasi berpengaruh terhadap kecenderungan kecurangan melalui perilaku tidak etis

\section{Otoritas pimpinan dan kecenderungan kecurangan}

Perilaku pegawai di dalam intansi terbentuk dari cara pimpinan dalam mencapai sasaran organisasi dan memberikan motivasi. Amrizal (2004) menyatakan bahwa kecurangan bisa terjadi apabila pegawai terlalu diatur dalam bekerja, disalahgunakan atau ditempatkan dengan tekanan besar untuk mencapai sasaran dan tujuan keuangan. Oleh karena ini, pimpinan harus menjadi teladan bagi pegawainya dalam tugas agar pegawai merasa bahwa apa yang mereka kerjakan didukung oleh pimpinan, sehinga dapat meminimalisir kemungkinan untuk melakukan kecurangan.

Menurut Association of Certified Fraud Examiners (2017), sikap atasan yang tidak menjadi teladan merupakan bentuk kelemahan utama yang menyebabkan terjadinya fraud, bahkan atasanpun justru menjadi pelaku utama fraud. Oleh karena itu, pimpinan sangat berperan dalam perilaku yang ditimbulkan oleh pegwainya, ibaratnya perilaku pegawai merupakan cerminan dari perilaku pimpinan.

Penelitian Murphy \& Mayhew (2013) menemukan bahwa adanya petunjuk/otoritas atasan meningkatkan perilaku kecurangan pelaporan. Indriani, Suroso, \& Maghfiroh (2016) dalam hasil penelitiannya menjelaskan bahwa tekanan berupa otoritas pimpinan memiliki hubungan yang positif terhadap kecenderungan terjadinya perilaku kecurangan. individu akan melakukan tindakan yang diperintahkan oleh pimpinannya meskipun hal tersebut tidak sesuai dengan prinsip yang dimiliknya.

H2 : Otoritas pimpinan berpengaruh positif terhadap kecenderungan kecurangan

Sistem pengendalian internal, kecenderungan kecurangan dan perilaku tidak etis

Kesempatan untuk melakukan kecurangan salah satunya berasal dari lemahnya sistem pengendalian internal dalam organisasi tersebut. Penelitian Arles (2014) 
menunjukkan bahwa kesempatan timbul karena lemahnya pengendalian internal untuk pencegahan dan pendekteksian, sehingga memberi keleluasaan bagi pelaku kecurangan melakukan tindakannya. Sedangkan penelitian yang dilakukan oleh Syahadat \& Damayanti (2017) memberikan hasil bahwa jika fungsi pengendalian internal yang terdiri dari lingkungan pengendalian, penilaian risiko, aktivitas control, informasi dan komunikasi, serta monitoring berjalan dengan baik di intansi pemerintah, maka peluang untuk melakukan tindakan kecurangan akan semakin kecil.

Shintadevi (2015) dalam penelitiannya memperoleh hasil bahwa sistem pengendalian internal memiliki pengaruh terhadap kecenderungan kecurangan baik secara langsung, maupun melalui perilaku tidak etis. Artinya, pengendalian internal yang lemah akan membuka peluang bagi seseorang untuk memanfaatkan keadaan dengan melakukan kecurangan.

$\mathrm{H} 3 \mathrm{a}$ : Sistem pengendalian internal berpengaruh negatif terhadap kecenderungan kecurangan

$\mathrm{H} 3 \mathrm{~b}$ : Sistem pengendalian internal berpengaruh terhadap kecenderungan kecurangan melalui perilaku tidak etis

\section{Asimteri informasi, kecenderungan kecurangan, dan perilaku tidak etis}

Asimetri merupakan keadaan dimana terjadi ketidakseimbangan informasi yang diperoleh oleh pihak principal dan agent (Scoot, 2009). Kondisi tersebut dapat membuka peluang bagi pegawai untuk melakukan kecurangan dengan menyajikan informasi keuangan yang tidak sesuai dengan sebenarnya. Sehingga keberadaan asimetri informasi akan menimbulkan permasalahan perilaku disfungsional bagi orang yang memiliki informasi dengan orang yang memanfaatkan informasi tersebut (Kusumastuti, 2012).

Penelitian Aranta (2013) yang menguji kecenderungan seseorang dalam melakukan kecurangan dengan menggunakan variabel asimetri informasi, memperoleh hasil bahwa semakin tinggi asimetri informasi maka kecenderungan kecurangan yang dilakukan oleh aparat juga akan semakin meningkat. Hasil yang sama juga diperoleh dari penelitian Indriastuti, Agusdin, \& Animah, (2016); Kusuma \& Andreina (2017) bahwa asimetri informasi berpengaruh positif terhadap kecenderungan kecuranga. Artinya, semakin tinggi asimetri 
informasi, maka akan semakin tinggi pula kemungkinan terjadinya kecurangan dalam instansi tersebut.

Penelitian Bestari, Azlina, \& Julita (2016) yang menguji pengaruh asimetri informasi terhadap kecenderungan kecurangan akuntansi melalui perilaku tidak etis, memberikan hasil bahwa semakin tinggi asimetri informasi akan semakin tinggi pula perilaku tidak etis yang akan berdampak pada kecenderungan untuk melakukan kecurangan.

$\mathrm{H} 4 \mathrm{a} \quad$ Asimteri informasi berpengaruh positif terhadap kecenderungan kecurangan

$\mathrm{H} 4 \mathrm{~b}$ : Asimetri informasi berpengaruh terhadap kecenderungan kecurangan melalui perilaku tidak etis

\section{Penegakan peraturan, kecenderungan kecurangan, dan "perilaku tidak etis"}

Kurang efektifnya penegakan peraturan baik itu dalam organisasi secara keseluruhan maupun dalam segala kegiatan yang dijalankan oleh organisasi akan membuka peluang yang mengarah pada perilaku menyimpang (Usman, 2017). Penelitian yang dilakukan oleh Mustika et al., (2016) menunjukkan bahwa penegakan peraturan yang tinggi dalam suatu organisasi, maka kemungkinan terjadinya kecurangan akan semakin rendah. Demikian pula penelitian Adi, Ardiyani, \& Ardianingsih, (2016) yang meneliti faktor-faktor penentu fraud memberikan hasil bahwa penegakan peraturan harus dilaksanakan dan dipatuhi oleh semua pihak yang ada dalam organisasi, akrena peraturan termasuk salah satu pengendalian agar kegiatan dalam organisasi berjalan sebagaimana seharusnya. Jika peraturan tidak dilaksanakan, akan memungkinkan terjadinya kecurangan dari orang-orang yang terlibat baik secara langsung maupun tidak langsung dalam kegiatan pada organisasi tersebut.

Penelitian Yulianti, DP, \& Rofika (2016) memberikan hasil penegakan hukum memiliki pengaruh terhadap kecenderungan kecurangan dengan perilaku tidak etis sebagai mediasi. tegaknya hukum disuatu instansi akan menurukan perilaku tidak etis dan menimbulkan efek jera bagi pelaku.

H5a Penegakan peraturan berpengaruh negatif terhadap kecenderungan kecurangan 
$\mathrm{H} 5 \mathrm{~b}$ : Penegakan peraturan berpengaruh terhadap kecenderungan kecurangan melalui perilaku tidak etis

\section{Penalaran moral, kecenderungan kecurangan, dan "perilaku tidak etis"}

Dalam teori penalaran moral Kohlberg (1995) dalam Indriani et al., (2016) disebutkan bahwa pengetahuan akan penalaran moral dapat digunakan untuk mengetahui kecenderungan individu melakukan suatu tindakan tertentu, terutama terkait dengan dilemma etika berdasarkan penalaran moralnya. Moralitas aparat yang rendah akan dapat dengan mudah menimbulkan perilaku tidak etis dengan cara memanfaatkan wewenang yang dimiliki untuk memaksimalkan keuntungan pribadi tanpa memikirkan akibatnya terhadap organisasi. Perilaku tidak etis tersebut akhirnya meningkatkan terjadinya kecenderungan untuk melakukan kecurangan.

Penelitian Wilopo (2006) menemukan bahwa semakin tinggi level penalran moral individu akan semakin cenderung tidak berbuat curang. Sama halnya dengan penelitian Mazar, Amir, \& Ariely (2008) dalam Mulia, Febrianto, \& Kartika (2017) yang memberikan hasil bahwa jika seseorang diingatkan pada suatu nilai moral yang seharusnya dimiliki, maka ia tidak akan melakukan kecurangan jika kesempatan untuk melakukan kecurangan itu ada karena pada saat itu ia berada pada level moral yang tinggi. Juga penelitian Bestari et al., (2016) memberikan hasil bahwa moralitas memiliki hubungan yang signifikan terhadap kecenderungan kecurangan melalui perilaku tidak etis.

$\mathrm{H6a}$ Penalaran moral berpengaruh negatif terhadap kecenderungan kecurangan

H6b : Penalaran moral berpengaruh terhadap kecenderungan kecurangan melalui perilaku tidak etis

\section{Perilaku tidak etis dan kecenderungan kecurangan}

Prinsip etika suatu manajemen diwakili oleh perilaku pemimpin dalam pengelolaan organisasi. Jika perilaku yang ditunjukkan oleh pemimpin cenderung tidak etis maka dapat menyebabkan terjadinya kecenderungan kecurangan (Kusumastuti, 2012). Penelitian Mustika et al., (2016) dan Maula (2017) memberikan hasil bahwa perilaku tidak etis memiliki pengaruh terhadap kecenderungan melakukan fraud. Hal ini menunjukkan semakin tinggi 
tingkat perilaku tidak etis pegawai maka akan meningkatkan kecenderungan pegawai tersebut melakukan fraud.

H7 : Perilaku tidak etis berpengaruh positif terhadap kecenderungan kecurangan

\section{METODE PENELITIAN}

\section{Lokasi dan sampel}

Penelitian ini dilakukan pada Organisasi Perangkat Daerah Pemerintah Provinsi Papua sebanyak 25 OPD. Pemilihan OPD yang dijadikan sebagai lokasi dalam penelitian ini berdasarkan Hasil Pemeriksaan BPK atas LKPD Provinsi Papua TA 2016, dimana terdapat beberapa OPD yang masuk dalam daftar BPK atas ketidakpatuhan dan kecurangan. Populasi dalam penelitian ini adalah Aparatur Sipil Negara dalam lingkungan OPD Provinsi Papua. Metode penyampelan yang digunakan adalah metode probability sampling, dengan teknik sampling yaitu cluster sampling. Dengan demikian yang menjadi sampel dalam penelitian ini adalah Kepala OPD, Bendahara, Kasubag Keuangan dan Staf.

\section{Jenis Penelitian dan Sumber Data}

Penelitian ini adalah penelitian kuantitatif yaitu penelitian yang menguji hipotesishipotesis yang diambil dari tiap variabel penelitian dengan angka kemudian dilakukan analisis data. Sumber data yang digunakan dalam penelitian ini adalah data primer, dengan metode pengumpulan data survey berupa kuisioner yang berisi daftar pernyataan yang akan diberikan kepada responden untuk diisi dengan tujuan untuk mendapatkan informasi dari responden.

\section{Pengukuran variabel}

\section{Kecenderungan Kecurangan (fraud)}

Fraud adalah perbuatan-perbuatan melawan hukum yang dilakukan dengan sengaja atau tujuan tertentu yang dilakukan oleh orang-orang dalam atau luar organisasi untuk mendapatkan keuntungan pribadi atau kelompok secara langsung atau tidak langsung merugikan pihak lain (Karyono, 2013;4). Indikator yang digunakan untuk mengukur kecenderungan kecurangan dikembangkan dari jenis-jenis kecurangan menurut Association 
of Certified Fraud Examiners (2018) yang diadopsi dari penelitian Mustika et al., (2016), terdiri dari kecurangan laporan keuangan, penyalahgunaan aset dan korupsi. Instrumen penelitian diukur dengan menggunakan Skala Likert 1-5.

\section{Kesesuaian Kompensasi}

Kompensasi merupakan semua balas jasa baik yang berupa uang, barang langsung dan tidak langsung yang diberikan kepada karyawan atas kontribusi dalam mencapai tujuan atau sasaran organisasi (Setiawan, 2012). Indikator yang digunakan untuk mengukur kesesuaian kompensasi dikembangkan oleh Gibson et al., (1997) dalam Wilopo (2006) yang diadopsi dari penelitian Lailiyah dan mustika, terdiri dari (1) kompensasi, (2) pengakuan organisasi atas keberhasilan dalam melaksanakan pekerjaan, (3) promosi, (4) penyelesaian tugas, (5) pencapaian sasaran, dan (6) pengembangan pribadi. Instrumen penelitian diukur dengan menggunakan skala Likert 1-5.

\section{Otoritas Pimpinan}

Otoritas pimpinan merupakan kapasitas yang ada pada pimpinan, berdasarkan jabatan formal untuk membuat keputusan yang mempengaruhi perilaku bawahan. Indikator yang digunakan untuk mengukur otoritas pimpinan berdasarkan penelitian Indriani et al., (2016) dan disesuaiakan oleh peneliti, terdiri (1) adanya tekanan dalam pelaksanaan pekerjaan, (2) adanya intervnesi pimpinan terhadap hasil pekerjaan, (3) adanya perintah pimpinan yang bertentangan dengan peraturan, dan (4) adanya keharusan melaksanakan perintah pimpinan. Instrumen yang digunakan diukur dengan menggunakan Skala Likert 15.

\section{Sistem Pengendalian Internal}

Pengendalian internal meliputi struktru organisasi, metode dan ukuran-ukuran yang dikoordinasikan untuk menjaga kekayaan organisasi, mengecek ketelitian dan keandalan data akuntansi, mendorong efisiensi, dan mendorong dipatuhinya kebijakan manajemen (Mulyadi, 2010). Indikator yang digunakan untuk mengukur efektifitas pengendalian internal berdasarkan PP No. 60 Tahun 2008 tentang Sistem Pengendalian Internal Pemerintah yang diadopsi dari penelitian Mustika et al., (2016), yang terdiri dari (1) lingkungan pengendalian, 
(2) penilaian risiko, (3) kegiatan pengendalian, (4) informasi dan komunikasi, serta (5) pemantauan. Instrumen yang digunakan diukur dengan Skala Likert 1-5.

\section{Asimetri Informasi}

Asimetri informasi adalah situasi dimana terjadi ketidakselarasan informasi dengan pihak yang membutuhkan informasi (Wilopo, 2006). Indikator yang digunakan untuk mengukur asimetri informasi diadopsi dari penelitian Mustika et al., (2016), yang terdiri dari (1) situasi dimana pihak intern instansi memiliki informasi yang lebih baik atas aktivitas, (2) situasi dimana pihak intern instansi mengetahui hubungan output dan input dalam bagiannya,(3) situasi dimana pihak intern instansi lebih mengetahui potensi kerja yang menjadi tanggungjawabnya, (4) situasi dimana pihak intern instansi lebih mengetahui teknis pekerjaannya dibandingkan pihak luar instansi, (5) situasi dimana pihak intern instansi lebih mengetahui faktor eksternal dalam bidang yang menjadi tanggungjawabnya dibanding pihak luar instansi, dan (6) situasi dimana pihak intern instansi lebih mengerti apa yang dapat dicapai dalam bidang yang menjadi tanggungajawabnya disbanding pihak luar instansi. Instrumen penelitian diukur dengan menggunakan Skala Likert 1-5.

\section{Penegakan Peraturan}

Penegakan peraturan adalah upaya yang dilakukan untuk menegakkan peraturan dan norma-norma yang ada, sebagai pedoman bagi seseorang untuk berperilaku dalam kehidupan berorganisasi (Indriani et al., 2016). Indikator yang digunakan untuk mengukur penegakan peraturan diadopsi dari penelitian Mustika et al., (2016) yang terdiri dari (1) ketaatan terhadap hukum, (2) proses penegakan hukum, (3) peraturan organisasi, (4) disiplin kerja, dan (5) tanggungjawab. Instrument penelitian diukur menggunakan Skala Likert 1-5.

\section{Penalaran Moral}

Moralitas mengacu pada kemampuan pertimbangan-pertimbangan moral berdsarkan penalaran kognitif individu yang melandasi cara individu tersebut menyelesaikan masalah sosial yang dihadapinya sesuai dengan Teori Perkembangan Moral Kohlberg (1969) yang menyatakan bahwa moral berkembang melalui tiga tahapa, yaitu tahapan pre-conventional, tahapan conventional, dan tahapan post-conventional. Indikator dalam penelitian ini diadopsi 
dari Indriani et al., (2016); Puspasari \& Surwardi, (2012) dengan menggunakan instrument defining issues test yang dikembangkan oleh Rest, Narvaez, Thoma, \& Bebeau, (1999). Instrument ini berbentuk kasus dilema etika, yang diukur melalui enam butir pernyataan yang mengukur tinggi rendahnya moralitas individu.

\section{Perilaku Tidak Etis}

Perilaku tidak etis adalah perilaku yang tidak sesuai dengan norma-norma sosial yang diterima secara umum, sehubungan dengan tindakan yang bermanfaat atau membahayakan (Griffin dan Ebert, 2006). Indikator yang digunakan untuk mengukur perilaku tidak etis dikembangkan oleh Tang \& Chius (2003) yang diadopsi dari Wilopo (2008) dan Mustika et al.,(2016), terdiri dari (1) perilaku yang menyalahgunakan kedudukan, (2)perilaku yang menyalahgunakan sumber daya organisasi, (3) perilaku yang menyalahgunaan kekuasaan, (4) perilaku yang tidak berbuat apa-apa, dan (5) perilaku yang mengabaikan peraturan. Instrument penelitian diukur dengan menggunakan Skala Likert 1-5.

\section{Analisis Data}

Alat analisis data dalam penelitian ini menggunakan pendekatan Structural Equation Model (SEM) dengan metode Partial Least Square (PLS) dengan menggunakan software WrapPLS 6.0. Menurut (Ghozali \& Latan, 2014), PLS merupakan metode analisis yang powerfull karena tidak didasarkan pada banyak asumsi.

\section{HASIL PENELITIAN DAN PEMBAHASAN}

\section{Analisis Data}

\section{Evaluasi Outer Model}

Terdapat tiga kriteria di dalam penggunaan teknik analisis data dengan WrapPLS untuk menilai outer model yaitu convergent validity, discriminant validity dan composite reliability.

a. Convergent Validity. Dapat dilihat dari korelasi antara skor indikator dengan skor konstruknya (loading factor) dengan kriteria nilai loading factor dari setiap indikator 
lebih besar dari 0,70 dapat dikatakan valid. Selanjutnya untuk nilai $p$-value $<0,50$ dianggap signifikan. Menurut Hulland (1999) dalam Ghozali \& Latan, (2014), untuk tahap pengembangan kosntruk dan skala pengukuran atau pengambangan instrument penelitian, nilai faktor laoding 0,4-0,5 dianggap cukup. Oleh karena itu, loading factor antara 0,40-0,70 harus tetap dipertimbangkan untuk dipertahankan apabila nilai $\operatorname{AVE}>0,50$. Namun, apabila nilai AVE tidak sesuai, penghapusan indikator dengan loading antara 0,40-0,70 dilakukan apabila indikator tersebut dapat meningkatkan AVE dan composite reliability di atas nilai batasnya.

b. Discriminant Validity, dinilai dari cross loading pengukuran dengan konstruk. Ada dua cara untuk mengevaluasi terpenuhinya validitas diskriminan, pertama, dengan melihat loading konstruk laten yang akan diprediksi indikatornya/dimensi lebih baik dari pada konstruk lainnya. Jika korelasi konstruk dengan pokok pengukuran (setiap indikator) lebih besar daripada ukuran konstruk lainnya maka validitas diskriminan terpenuhi, kedua, untuk dapat menganalsia discriminant validity yaitu dengan kriteria AVE. kriteria yang digunakan adalah akar kuadrat (square roots) AVE, yaitu kolom diagonal dan diberi tanda kurung harus lebih tinggi dari korelasi antar variabel laten pada kolom yang sama.

c. Composite Reliability, dapat diukur dengan dua kriteria yaitu composite reliability dan cronbach's alpha. Composite reliability data yang memiliki composite reliability $>0,8$ mempunyai reliabilitas tinggi. AVE diharapkan $>0,5$ dan nilai cronbach's alpha dinyatakan reliabel jika $>0,6$ untuk semua konstruk.

Tabel 1. Output Latent Variable Coefficients setelah penghapusan indicator

\begin{tabular}{|c|c|c|c|c|c|c|c|c|}
\hline & KKO & $O P$ & SPI & Al & PP & PM & PTE & KK \\
\hline R-squared & & & & & & & 0.054 & 0.269 \\
\hline Adj. R-squared & & & & & & & 0.008 & 0.218 \\
\hline Composite reliab. & 0.823 & 0.854 & 0.922 & 0.932 & 0.931 & 0.908 & 0.879 & 0.872 \\
\hline Cronbach's alpha & 0.569 & 0.771 & 0.902 & 0.912 & 0.889 & 0.865 & 0.793 & 0.779 \\
\hline Avg. var, extrac, & 0.699 & 0.594 & 0.596 & 0.696 & 0.819 & 0.713 & 0.709 & 0.695 \\
\hline Full collin. VIF & 1.227 & 1.600 & 1.948 & 1.389 & 1.706 & 1.368 & 1.079 & 1.367 \\
\hline Q-squared & & & & & & & 0.068 & 0.277 \\
\hline
\end{tabular}


Tabel 2. Coefficient Among Latent Variable

\begin{tabular}{|r|r|r|r|r|r|r|r|r|}
\hline \hline & \multicolumn{1}{c}{ KKO } & \multicolumn{1}{c}{ OP } & \multicolumn{1}{c}{ SPI } & \multicolumn{1}{c}{ AI } & \multicolumn{1}{c}{ PP } & PM & \multicolumn{1}{c|}{ PTE } & \multicolumn{1}{c|}{ KK } \\
\hline KKO & $(0.836)$ & -0.018 & 0.402 & 0.118 & 0.204 & 0.091 & -0.109 & -0.076 \\
\hline OP & -0.018 & $(0.770)$ & -0.105 & 0.395 & 0.010 & -0.444 & 0.173 & 0.452 \\
\hline SPI & 0.402 & -0.105 & $(0.772)$ & 0.228 & 0.620 & 0.065 & -0.075 & -0.002 \\
\hline AI & 0.118 & 0.395 & 0.228 & $(0.834)$ & 0.271 & -0.283 & -0.027 & 0.294 \\
\hline PP & 0.204 & 0.010 & 0.620 & 0.271 & $(0.905)$ & -0.003 & 0.048 & 0.054 \\
\hline PM & 0.091 & -0.444 & 0.065 & -0.283 & -0.003 & $(0.844)$ & -0.163 & -0.397 \\
\hline PTE & -0.109 & 0.173 & -0.075 & -0.027 & 0.048 & -0.163 & $(0.842)$ & 0.080 \\
\hline KK & -0.076 & 0.452 & -0.002 & 0.294 & 0.054 & -0.397 & 0.080 & $(0.833)$ \\
\hline
\end{tabular}

Berdasarkan tabel diatas terlihat bahwa convergent validity telah terpenuhi setelah dilakukan penghapusan beberapa indikator yang memiliki nilai loading factor $<0,70$ dimana nilai AVE juga sudah terpenuhi yaitu $>0,50$. Selain itu, discriminant validity juga sudah terpenuhi. Hal tersebut ditunjukkan dengan korelasi konstruk dengan setiap indikator lebih besar daripada ukuran konstruk lainnya, serta nilai akar kuadrat AVE yang lebih besar dari koefisien korelasi antara semua konstruk dengan konstruk lainnya dalam model.

Berdasarkan uji reliabilitas dengan melihat nilai composite reliability dan cronbach's alpha terlihat bahwa seluruh kontruk menunjukkan nilai cronbach's alpha dan composite reliability sudah lebih dari 0,7 , namun ada satu konstruk yang nilai cronbach's alpha di bawah 0,7 yaitu kesesuaian kompensasi. Meskipun nilai cronbach's alpha konstruk tersebut di bawah 0,7 namun nilai tersebut masih dapat diterima (Hair et al., 2008) dalam Abdillah \& Jogiyanto (2015).

\section{Evaluasi Inner Model}

Tahap berikutnya adalah melakukan evaluasi inner model yang meliputi uji kecocokan model (model fit) path coefficient dan $\mathrm{R}^{2}$. Untuk menilai hasil suatu model dikatakan fit dalam program WrapPLS 6.0 dapat dilihat dari output general result.

\section{Pengujian Hipotesis}

Pengujian hipotesis dimaksudkan untuk membuktikan kebenaran dugaan penelitian atau hipotesis. Hasil korelasi antar konstruk diukur dengan melihat nilai path coefficients dan tingkat signifikansinya. Tingkat signifikansi yang dipakai dalam penelitian ini adalah $5 \%$. 
Hipotesis akan diterima jika nilai $p<0,05$. Hasil output model WrapPLs 6.0 adalah sebagai berikut:

Dari hasil output WrapPLS 6.0 di atas dapat secara ringkat dilihat pada hasil uji hipotesis pada tabel di bawah ini:

Tabel 3. Hasil Output Path Coefficients Model Direct and Indirect Effect

\begin{tabular}{|l|l|l|l|}
\hline \multicolumn{1}{|c|}{ Variabel } & \multicolumn{1}{c|}{ Path Coefficients } & $\boldsymbol{P}$ value & Keterangan \\
\hline $\mathrm{KKO} \rightarrow \mathrm{KK}$ & -0.086 & 0.122 & Ditolak \\
\hline $\mathrm{OP} \rightarrow \mathrm{KK}$ & 0.319 & $<0.001$ & Diterima \\
\hline $\mathrm{SPI} \rightarrow \mathrm{KK}$ & 0.051 & 0.244 & Ditolak \\
\hline $\mathrm{Al} \rightarrow \mathrm{KK}$ & 0.099 & 0.090 & Ditolak \\
\hline $\mathrm{PP} \rightarrow \mathrm{KK}$ & 0.010 & 0.446 & Ditolak \\
\hline $\mathrm{PM} \rightarrow \mathrm{KK}$ & -0.225 & 0.001 & Diterima \\
\hline $\mathrm{PTE} \rightarrow \mathrm{KK}$ & -0.016 & 0.416 & Ditolak \\
\hline $\mathrm{KKO} \rightarrow \mathrm{PTE} \rightarrow \mathrm{KK}$ & 0.001 & 0.492 & Ditolak \\
\hline $\mathrm{SPI} \rightarrow \mathrm{PTE} \rightarrow \mathrm{KK}$ & 0.002 & 0.487 & Ditolak \\
\hline $\mathrm{Al} \rightarrow \mathrm{PTE} \rightarrow \mathrm{KK}$ & 0.001 & 0.490 & Ditolak \\
\hline $\mathrm{PP} \rightarrow \mathrm{PTE} \rightarrow \mathrm{KK}$ & -0.002 & 0.482 & Ditolak \\
\hline $\mathrm{PM} \rightarrow \mathrm{PTE} \rightarrow \mathrm{KK}$ & 0.003 & 0.479 & Ditolak \\
\hline
\end{tabular}

Sumber: Data Primer diolah, 2018

\section{Pembahasan}

\section{Kesesuaian Kompensasi, Kencenderungan Kecurangan dan perilaku Tidak Etis}

Hasil pengujian menunjukkan bahwa $\mathrm{H} 1 \mathrm{a}$ : ditolak dan $\mathrm{H} 1 \mathrm{~b}$ : ditolak sehingga dapat dikatakan bahwa kesesuain kompensasi tidak memiliki pengaruh baik secara langsung terhadap kecenderungan kecurangan maupun melalui perilaku tidak etis. Hasil penelitian ini tidak sejalan dengan penelitian Indriastuti et al., (2016) dan Kurrohman, Pratiwi, \& Andriana (2017) yang menyatakan bahwa kesesuaian kompensasi memiliki pengaruh terhadap kecenderungan kecurangan. Namun sejalan dengan penelitian (Indriani et al., 2016; Mustika et al., 2016; Permatasari et al., 2017; Pratiwi et al., 2016) yang menyatakan bahwa konstruk kesesuaian kompensasi merupakan variabel yang tidak berpengaruh terhadap kecenderungan kecurangan.

Tidak adanya pengaruh kesesuaian kompensasi terhadap kecenderungan kecurangan di Pemerintah Provinsi Papua dimungkinkan karena saat ini di Pemerintah Daerah pemberian kompensasi menjadi lebih ketat diakrenakan semakin ketatnya pemeriksaan dan KPK mulai menekankan tidak diperbolehkannya kompensasi yang 
berlebihan karena pegawai telah menerima tunjangan kinerja sehingga tidak ada kecenderungan untuk melakukan kecurangan. Selain itu juga, karena pegawai telah memahami bahwa kompensasi berupa gaji atau honor serta kenaikan jabatan atau promosi merupakan hal yang tidak dapat dipilih oleh para pegawai karena gaji dan kompensasi yang diberikan telah sesuai dengan jabatan dan golongan pegawai.

Sama seperti kesesuaian kompensasi yang tidak berpengaruh langsung terhadap kecenderungan kecurangan. Kesesuaian kompensasi juga tidak berpengaruh terhadap kecenderungan kecurangan melalui perilaku tidak etis. Artinya, bahwa sesuai atau tidaknya kompensasi yang diterima oleh pegawai akan tetap ada indikasi untuk melakukan perilaku tidak etis. Karena saat ini, perilaku tidak etis contohnya penyalahgunaan wewenang dilakukan oleh orang yang memiliki kompensasi/penghasilan yang tinggi. Jadi, tinggi atau rendahnya kompensasi yang diterima, indikasi untuk melakukan perilaku tidak etis dan kecurangan itu tetap ada.

\section{Otoritas Pimpinan dan Kecenderungan Kecurangan}

Hasil pengujian menunjukkan bawha H2: diterima sehingga dapat dikatakan bahwa otoritas pimpinan memiliki pengaruh positif dan signifikan terhadap kecenderungan kecurangan. Hasil penelitian ini sejalan dengan (Indriani et al., 2016; Murphy \& Mayhew, 2013; Rafinda, 2013; Sofyani \& Pramita, 2014) yang dalam penelitiannya menunjukkan bahwa tekanan situasional berupa otoritas dari pimpinan akan mempengaruhi dalam melakukan kecurangan.

Dalam suatu organisasi otoritas dari pimpinan masih cukup dominan, hal ini ditandai dengan masih banyaknya kebijakan-kebijakan yang dilaksanakan berdasarkan pada apa yang diinginkan pimpinan. Ada suatu pola hubungan yang terjadi yang disebut hubungan ptron-klien, yang secara etimologis partron berarti seseorang yang memiliki kekuasaan (power), memiliki status atau pengaruh, sedangkan klien berarti bawahan atau orang yang diperintah atau disuruh. Pola hubungan ini juga berkaitan dengan bagaimana seorang pimpinan menggunakan pengaruh atau kekuasaannya untuk mempengaruhi bawahannya dalam bertindak dan bawahan selalu menjadi pihak yang tidak punya banyak pilihan. 
Karena seseorang dalam posisi otoritas memiliki pengaruh lebih besar atas istuasi tertentu atau lingkungan (Arles, 2014), yang dapat menyebabkan individu merasakan tekanan untuk patuh terhadap perintah individu lain yang berada pada posisi otoritas. Dimana otoritas pimpinan dapat memberikan efek langsung kepada perilaku seseorang, sehingga seseorang akan cenderungan melakukan apapun yang diperintahkan oleh pimpinan.

\section{Sistem Pengendalian Internal, Kecenderungan Kecurangan dan Perilaku Tidak Etis}

Hasil pengujian menunjukkan bahwa H3a: ditolak dan H3b: ditolak sehingga dapat dikatakan bahwa sistem pengendalian internal tidak memiliki pengaruh baik secara langsung terhadap kecenderungan kecurangan maupun melalui perilaku tidak etis. Hasil ini sejalan dengan penelitian (Adi et al., 2016; Mustika et al., 2016; Permatasari et al., 2017) yang menyatakan bahwa sistem pengendalian internal tidak berpengaruh terhadap kecenderungan kecurangan dan penelitian Bestari et al., (2016) dalam penelitiannya menyatakan bahwa sistem pengendalian internal tidak memiliki pengaruh terhadap kecenderungan kecurangan melalui perilaku tidak etis.

Kondisi ini bisa terjadi karena sebaik apapun sistem yang diciptakan akan selalu ada kekurangnnya. Karena tidak ada sistem yang sempurna untuk mencegah seseorang melakukan kecurangan. Sistem yang baik sekalipun tidak akan dapat berjalan bilamana sekelompok pegawai berkolusi atau bekerjasama untuk melanggar sistem itu. Dengan kolusi, akan terlihat di permukaan seolah-olah sistem dipatuhi tetapi pada hakekatnya dilanggar. Sehingga efektif atau tidak efektifnya sistem pengendalian internal tidak menjamin menurunkan kecenderungan untuk melakukan kecurangan, karena walaupun sistem pengendalian internal sudah efektif namun kecenderungan untuk melakukan kecurangan masih tetap ada (Fauzya, 2017).

Hal ini juga berkaitan dengan bagaimana sistem pengendalian internal tidak berpengaruh melalui perilaku tidak etis. Menurut Griffin dan Ebert (2006) dalam Fitri, Nurazlina, \& Al Azhar (2016) perilaku tidak etis merupakan perilaku yang menurut keyakinan perseorang atau norma-norma sosial dianggap benar dan salah. Perilaku ini muncul karena 
lemahnya pengawasan dalam instansi sehingga memudahkan orang-orang dalam untuk berperilaku tidak etis. Namun, hasil pengujian dalam penelitian ini tidak menunjukkan adanya pengaruh sistem pengendalian internal melalui perilaku tidak etis, artinya sistem pengendalian yang baik sekalipun belum tentu mampu untuk menurunkan niat seseorang berperilaku tidak etis, karena setiap sistem yang baikpun pasti memiliki celah yang dapat digunakan oleh orang-orang yang tidak bertanggungjawab untuk kepentingan diri sendiri/kelompoknya.

\section{Asimetri informasi, Kecenderungan Kecurangan dan Perilaku Tidak Etis}

Hasil pengujian menunjukkan bahwa H4a: ditolak dan H4b: ditolak sehingga dapat dikatakan bahwa asiometeri informasi tidak berpengaruh terhadap kecenderungan kecurangan baik secara langsung maupun melalui perilaku tidak etis. Hasil ini sejalan dengan penelitian (Indriani et al., 2016; Mustika et al., 2016)yang dalam peneltiiannya menyatakan bahwa asimetri informasi tidak berpengaruh terhadap kecenderungan kecurangan, sehingga meskipun tidak ada asimetri informasi namun kecurangan tetap bisa terjadi.

Tidak adanya pengaruh antara asimetri informasi terhadap perilaku tidak etis dan kecenderungan kecurangan mengindikasikan bahwa seseorang berperilaku bukan karena adanya asimetri informasi, tapi karena niat untuk melakukan kecurangan itu selalu saja ada meskipun dalam kondisi asimetri informasi yang rendah.

Hasil penelitian ini dapat dijelaskan dengan beberapa kasus pimpinan dan bawahan yang melakukan tindakan kecurangan secara bersama-sama demi memaksimalkan keuntungan pribadi masing-masing. Mereka menggunakan informasi dan pengetahuan yang mereka miliki untuk bersama-sama memanfaatkan kesempatan yang ada sehingga kesenjangan informasi yang terjadi tidak berpengaruh pada perilaku tidak etis dan kecenderungan untuk melakukan kecurangan.

\section{Penegakan Peraturan, Kecenderungan Kecurangan dan Perilaku Tidak Etis}

Hasil pengujian menunjukkan bahwa H5a: ditolak dan H5b: ditolak sehingga dapat dikatakan bahwa penegakan peraturan tidak memiliki pengaruh terhadap kecenderungan 
kecurangan baik secara langsung maupun melalui perilaku tidak etis. Hasil penelitian ini sejalan dengan penelitian (Indriani et al., 2016; Kurrohman et al., 2017; Yulianti et al., 2016) yang menyatakan bahwa penegakan peraturan tidak berpengaruh terhadap kecenderungan kecurangan.

Hasil ini tidak mendukung teori fraud triangle dan GONE yang menyatakan bahwa salah satu faktor seseorang melakukan perilaku tidak etis dan kecurangan adalah karena adanya kesempatan. Kesempatan untuk berbuat curang timbul karena lemahnya penegakan peraturan dalam suatu instansi. Hal tersebut karena masih banyaknya kasus kecurangan yang terjadi meskipun peraturan sudah memuat hal-hal yang boleh dan tidak boleh dilakukan serta hukumannya. Artinya, peraturan yang ditegakkan dalam suatu organisasi belum tentu mampu untuk menurunkan tingkan kecurangan yang terjadi.

\section{Penalaran Moral, Kecenderungan Kecurangan,"dan Perilaku Tidak Etis"}

Hasil pengujian menunjukkan bahwa $\mathrm{H} 6 \mathrm{a}$ : diterima dan $\mathrm{H} 6 \mathrm{~b}$ : ditolak sehingga dapat dikatakan bahwa penalaran moral memiliki pengaruh negative dan signifikan terhadap kecenderungan kecurangan, tetapi tidak memiliki pengaruh melalui perilaku tidak etis. Korompis et al., (2018) menyatakan moralitas individu akan mempengaruhi kecenderungan seseorang untuk melakukan kecurangan, yang artinya semakin tinggi tahapan moralitas individu, semakin individu memperhatikan kepentingan yang lebih luas dan universal dari pada kepentingan organisasi apalagi kepentingan individu, dan akan semakin rendah kecenderungan untuk melakukan kecurangan. Hasil ini sejalan dengan (Puspasari \& Surwardi, 2012; Indriani et al., 2016; Indriastuti et al., 2016; Mulia et al., 2017;) yang hasil penelitiannya menyatakan bahwa penalaran moral berpengaruh negatif terhadap kecenderungan kecurangan. Artinya, moral sangat berpengaruh terhadap bagaimana seseorang mengambil keputusan baik itu keputusan yang baik dan menguntungkan semua pihak, maupun keputusan yang kurang baik yang hanya mementingkan pihak tertentu.

Memiliki moral yang baik dalam bekerja berarti pegawai juga memiliki dedikasi yang tinggi terhadap instansi dan pemerintahan secara keseluruhan, sehingga kecenderungan untuk melakukan kecurangan demi kepentingan pribadi akan rendah. Dengan demikian, 
pegawai akan cenderung bekerja dengan baik untuk instansi tersebut. Sebaliknya, jika moral yang dimiliki pegawai rendah maka akan cenderung bekerja kurang baik dan dapat melakukan kecurangan dan akan merasionalkan hal tersebut sebagai hal yang wajar dikarenakan kurangnya kepedulian akan hasil pekerjaan, sehingga ketika melakukan kecurangan akan dianggap sebagai hal yang biasa. Kelsen (2002) dalam Satiene \& Toleikiene (2007) menyebutkan moralitas merupakan tanggungjawab yang berasal dari dalam diri seseorang, yang artinya bahwa seseorang bertindak berdasarkan moralitasnya. Satiane dalam penelitiannya juga menjelaskan bahwa seseorang yang bekerja mengaitkan tanggujawab pribadinya dengan aturan tetapi tidak dengan tanggungjawab moral, sehingga nilai-nilai moral sering dibaikan, padahal tanggungjawab moral lebih penting untuk mengurangi korupsi/kecurangan.

\section{Perilaku Tidak Etis dan Kecenderungan Kecurangan}

Hasil pengujian menunjukkan bahwa $\mathrm{H} 7$ : ditolak sehingga dapat dikatakan bahwa perilaku tidak etis tidak memiliki pengaruh terhadap kecenderungan kecurangan. (Abuznaid, 2015) dalam penelitiannya menyatakan bahwa perilaku tidak etis dalam organisasi karena pegawai yang masuk berasal dari latar belakang yang berbeda sehingga memiliki motif yang berbeda. Salah satu contoh perilaku tidak etis adalah penyalahguaan wewenang, dimana seseorang memanfaatkan wewenang atau jabatan yang dimiliki untuk mencapai apa yang diinginkan meskipun hal tersebut merupakan suatu perbuatan yang tidak etis. Namun, sekarang ini kecurangan tidak hanya dilakukan oleh mereka yang memiliki wewenang tinggi, tetapi dilakukan oleh pegwai tingkat bawah atau semua lini jabatan yang ada dalam suatu instansi.

\section{SIMPULAN}

Berdasarkan hasil pengujian dan pembahasan penelitian, maka dapat ditarik kesimpulan bahwa kesesuaian kompensasi, sistem pengendalian internal, asimetri informasi, penegakan peraturan dan perilaku tidak etis tidak memiliki pengaruh terhadap kecenderungan kecurangan. Sedangkan, otoritas pimpinan dan penalaran moral berpengaruh dan signifikan terhadap kecenderungan kecurangan. Selain itu, perilaku tidak 
etis bukan merupakan variabel mediasi, karena tidak adanya pengaruh variabel kesesuaian kompensasi, otoritas pimpinan, sistem pengendalian internal, asimetri informasi, penegakan peraturan, dan penalaran moral terhadap kecenderungan kecurangan melalui perilaku tidak etis.

\section{DAFTAR PUSTAKA}

Abdillah, W., \& Jogiyanto. (2015). Partial Least Square (PLS): Alternatif Structural Equation Modeling (SEM) dalam Penelitian Bisnis. Yogyakarta: ANDI Yogyakarta.

Abdullahi, R., \& Mansor, N. (2015). Fraud Triangle Theory and Fraud Diamond Theory: Understanding the Convergent and Divergent For Future Research. International Journal of Academic Research in Accounting, Finance and Management Sciences, 5(4), 38-45.

Abuznaid, S. A. (2015). Unethical Practices in the Public Sector: Motivation and Behavior. Hebron University.

Adi, M. R. K., Ardiyani, K., \& Ardianingsih, A. (2016). Analisis Faktor-Faktor Penentu Kecurangan (Fraud) Pada Sekotr Pemerintahan:Studi Kasus Pada Dinas Pendapatan Pengelolaan Keuangan dan Aset Daerah Kota Pekalongan. Jurnal Litbang Kota Pekalongan, 10, 1-10.

Amrizal. (2004). Pencegahan Dan Pendeteksian Kecurangan Oleh Internal Auditor. BPKP.

Apriadi, R. N., \& Fachriyah, N. (2014). Determinan Terjadinya Fraud Di Institusi Pemerintahan. Jurnal IImiah Mahasiswa FEB Universitas Brawijaya, 3(1), 1-25.

Aranta, P. Z. (2013). Pengaruh Moralitas Aparat dan Asimetri Informasi terhadap Kecenderungan Kecurangan Akuntansi (Studi Empiris Pemerintah Kota Sawahlunto). EJurnal Akuntansi Universitas Negeri Padang.

Arles, L. (2014). Faktor - Faktor Pendorong Terjadinya Fraud: Predator vs. Accidental Fraudster Diamond theory Refleksi Teori Fraud Triangle (Klasik) Suatu Kajian Teoritis. Papper Ilmiah, 1-15.

Association of Certified Fraud Examiners. (2017). Survai Fraud Indonesia 2016. ACFE Indonesia Chapter. Jakarta.

Association of Certified Fraud Examiners. (2018). Report to the Nations: 2018 Global Study on Occupational Fraud and Abuse. Global Fraud Study.

Bestari, D. S., Azlina, N., \& Julita. (2016). Pengaruh Keefektifan Pengendalian Internal, Asimetri Informasi, dan Moralitas Individu Terhadap Kecenderungan Kecurangan Akuntansi dengan Perilaku Tidak Etis sebagai Intervening (Studi Empiris Pada Satuan Kerja Perangkat Daerah Provinsi Riau). JOM Fekon, 3(1), 1436-1447. 
Diany, Y. A., \& Ratmono, D. (2014). Determinan Kecurangan Laporan Keuangan: Pengujian Teori Fraud triangle. Fakultas Ekonomika dan Bisnis.

Fauzya, I. S. (2017). Pengaruh Keefektifan Sistem Pengendalian Internal, Kesesuaian Kompensasi, Moralitas Individu, dan Asimetri Informasi terhadap Kecenderungan Kecurangan Akuntansi dengan Perilaku Tidak Etis sebagai Variabel Intervening pada BPPKAD Kabupaten Sragen. Skripsi. Institu Agama Islam Negeri Surakarta.

Fitri, Y., Nurazlina, \& Al Azhar. (2016). Pengaruh Keefektifan Sistem Pengendalian Internal, Ketaatan Akuntansi, Asimetri Informasi, dan Moralitas Individu terhadap Kecenderungan Kecurangan Akuntansi dengan Perilaku Tidak Etis Sebagai Variabel Intervening (Studi Empiris Pada Satuan Kerja Perangka. JOM Fekon, 505-519.

Ghozali, I., \& Latan, H. (2014). Partial Least Squares Konsep, Metode dan Aplikasi Menggunakan WrapPls 5.0 (Third). Semarang: Badan Penerbit Universitas Diponegoro. Hadi, K. (2016). Korupsi Birokrasi Pelayanan Publik di Era Otonomi Daerah. Jurnal $\begin{array}{lllll}\text { Penelitian Politik, } 20 . & \text { R(1), } & \text { Retrieved }\end{array}$ http://ejournal.lipi.go.id/index.php/jppol/article/download/512/320

Indriani, I., Suroso, S., \& Maghfiroh, S. (2016). Penerapan Konsep Fraud Diamond Theory Dalam Mendeteksi Perilaku Fraud. Simposium Nasional Akuntansi XIX, Lampung.

Indriastuti, D. E., Agusdin, \& Animah. (2016). Analisis Pengaruh Asimetri Informasi, Pengendalian Internal, Persepsi Kesesuaian Kompensasi, Moralitas Individu, Dan Ketaatan Aturan Akuntansi Terhadap Kecurangan Akuntansi. Jurnal InFestasi, 12(3), 115-130.

Kassem, R., \& Higson, A. (2012). The New Fraud Triangle Model. Journal of Emerging Trends in Economics and Management Sciences, 3(3), 191-195.

Korompis, S. N., Saerang, D. P. E., \& Morasa, J. (2018). Pengaruh Moralitas Individu, Asimetri Informasi, dan Keefektifan Pengendalian Internal Terhadap Kecenderungan Kecurangan (Fraud) Berdasarkan Persepsi Pada Badan Pengelola Keuangan dan Barang Milik Daerah Provinsi Sulawesi Utara. Jurnal Riset Akuntansi Dan Auditing “Goodwill," 9(1).

Kurrohman, T., Pratiwi, E., \& Andriana. (2017). Deteksi Kecurangan (Fraud) di Sektor Pemerintah (Studi Empiris pada SKPD di Kabupaten Jember). Journal of Applied Managerial Accounting (JAMA), 1(2).

Kusuma, H., \& Andreina, R. . (2017). Social Science Determinants of Accounting Frauds: Perceptions of Indonesian Civil Servants. International Journal of Research in Business \& Social Science, 6(4), 11-21.

Kusumastuti, N. R. (2012). Analisis Faktor-Faktor yang Berpengaruh Terhadap Kecenderungan Kecurangan Akuntansi dengan Perilaku Tidak Etis Sebagai Variabel Intervening. 
Maula, K. (2017). Analisis Pengaruh Faktor- Faktor Pendorong Tindak Kecurangan terhadap Kecendrungan Aparatur Pemerintah Melakukan Fraud (Persepsi Pegawai Dinas Kabupaten Banyumas). Jurnal Unsika, 2(1), 273-287.

Mazar, N., Amir, O., \& Ariely, D. (2008). The Dishonesty of Honest People: A Theory of SelfConcept Maintenance. Journal of Marketing Research, 45(6), 633-644. https://doi.org/10.1509/jmkr.45.6.633

Mulia, M. H. K., Febrianto, R., \& Kartika, R. (2017). Pengaruh Moralitas Individu dan Pengendalian Internal terhadap Kecurangan: Sebuah Studi Eksperimental. Jurnal Akuntansi Dan Investasi, 18(2), 198-208.

Murphy, P. R., \& Mayhew, B. W. (2013). The Impact of Authority on Reporting Behavior, Rationalization and Affect. SSRN Electronic Journal.

Mustika, D., Hastuti, S., \& Heriningsih, S. (2016). Analisis Faktor-Faktor yang Mempengaruhi Kecenderungan Kecurangan (Fraud): Persepsi Pegawai Dinas Kabupaten Way Kanan Lampung. Simposium Nasional Akuntansi XIX, Lampung, 1-22.

Permatasari, D. E., Kurrohman, T., \& Kartika. (2017). Analisis Faktor-Faktor yang Mempengaruhi Terjadinya Kecenderungan Kecurangan ( Fraud) di Sektor Pemerintah ( Studi pada Pegawai Keuangan Pemerintah Kabupaten Banyuwangi ). Jurnal Keuangan Dan Perbankan, 14(1), 37-44.

Pratiwi, T., DP, N. E., \& Rofika. (2016). Pengaruh Penegakan Peraturan, Sistem Kompensasi, Ketaatan Aturan Akuntansi dan Moralitas Aparat Terhadap Kecenderungan Kecurangan Akuntansi dengan Perilaku Tidak Etis Sebagai Variabel Intervening Serta Pengaruhnya Terhadap Kinerja Instansi Pemerintah: Stu. JOM Fekon, $3(1)$.

Puspasari, N., \& Surwardi, E. (2012). Pengaruh Moralitas Individu dan Pengendalian Internal Terhadap Kecenderungan Kecurangan Akuntansi:Studi Eksperimen Pada Konteks Pemerintah Daerah. Simposium Nasional Akuntansi XV Banjarmasin, 1-30.

Rafinda, A. (2013). Kemampuan Prediksi Faktor Situasional dan Faktor Individual pada Perilaku Kecurangan Pelaporan. Simposium Nasional Akuntansi XIV, Manado, (September 2013).

Rest, J. R., Narvaez, D., Thoma, S. J., \& Bebeau, M. J. (1999). DIT2 : Devising and Testing a Revised Instrument of Moral Judgment. Journal of Education Psychology, 91(4), 644659.

Salle, A., \& Burg, E. van. (2019). Understanding the fiduciary risk of the special autonomy fund in the Papua Province, Indonesia. Social Science Research Network. Retrieved from https://papers.ssrn.com/sol3/papers.cfm?abstract_id=3336812

Satiene, G., \& Toleikiene, R. (2007). A Con-n-ec-tion- Between- Cor-r-up-tion an-d Un-ethic-al Behaviour- of Pub-lic- Offi-c-ials. Social Research, 2(10), 155-160. 
Shintadevi, P. F. (2015). Pengaruh Keefektifan Pengendalian Internal, Ketaatan Aturan Akuntansi dan Kesesuaian Kompensasi terhadap Kecenderungan Kecurangan Akuntansi dan Perilaku Tidak Etis sebagai Variabel Intervening. Jurnal Nominal, IV(2), 111-126.

Sofyani, H., \& Pramita, Y. . (2014). Otoritas Atasan, Retaliasi Dan Locus of Control Sebagai

Faktor-Faktor Yang Memengaruhi Perilaku Manipulasi Laporan Realisasi Anggaran. Simposium Nasional Akuntansi XVII Lombok, (December 2014), 1-19.

Syahadat, E. F., \& Damayanti, M. R. A. (2017). Faktor-Faktor yang berpengaruh terhadap Kecenderungan Fraud. Ekombis Sains, 02(02).

Usman, S. (2017). Analisis Faktor-Faktor yang Mempengaruhi Terjadinya Fraud di Sektor Pemerintahan (Studi Pada SKPD Kabupaten Luwu Timur).

Wilopo. (2006). Analisis Faktor-faktor yang Berpengaruh Terhadap Kecenderungan Kecurangan Akuntansi: Studi pada Perusahaan Publik dan Badan Usaha Milik Negara di Indonesia. Jurnal Riset Dan Akuntansi Indonesia, 9(3), 346-366.

Wilopo, R. (2008). Pengaruh Pengendalian Internal Birokrasi Pemerintah dan Perilaku Tidak Etis Birokrasi Terhadap Kecurangan Akuntansi di Pemerintahan: Persepsi Auditor Badan Pemeriksa Keuangan. Journal of Economics, Business \& Accountancy Ventura, 11(1).

Yulianti, D. . F., DP, E. . N., \& Rofika. (2016). Pengaruh Moralitas Individu, Penegakan Hukum, Keadilan Distributif, Keadilan Prosedural terhadap Kecenderungan Kecurangan Akuntansi dengan Perilaku Tidak Etis sebagai Variabel Intervening (Studi pada Satuan Kerja Perangkat Daerah Kabupaten Kampar). JOM Fekon, 3(1), 2177-2191. https://doi.org/e-issn 2355-6854 